\title{
Andrássy György
}

Pécsi Tudományegyetem ÁJK

\section{Nyelvek és nyelvi jogok a térben}

Térhez kötöttek lennének a nyelvi jogok, vagy legalábbis bizonyos

nyelvi jogok? Attól függốen tehát, hogy hol él valaki, más és más nyelvi jogok illetik meg? Milyen természetú jogok akkor a nyelvi jogok és milyen természetú a nyelvi igazságosság? Es megoldhatók-e azok a problémák, amelyek a nyelvi jogok körében - és persze nemcsak magyar összefüggésben - idóról idôre fölmerülnek?

\section{Bevezetés}

A nyelvi jogok problémája a nyelvkülönbség vagy nyelvi sokféleség jelenségéhez kapcsolódik. A jelenség Magyarországon régtől fogva ismert, már Szent István kitért rá Imre hercegnek írt Intelmeiben, mindazonáltal a nyelvi jogok kérdése a 18. században kezdett komolyabb üggyé válni: akkor, amikor már látszott, hogy a latin nyelvet nem lehet megtartani az ország hivatalos nyelveként. A helyzetet kiélezte, hogy II. József 1784-ben kelt nyelvrendelete a németet kívánta Magyarország hivatalos nyelvévé tenni, majd 1790-ben megkezdődött az a folyamat, amely 1844-ben elvezetett a magyar nyelv hivatalos nyelvvé nyilvánításához. A magyar nyelv államnyelvi jogállását a kiegyezést követően ismét törvénybe iktatta a magyar országgyülés: az 1868. évi XLIV. tc. ezzel kapcsolatos rendelkezési ugyanakkor széles körben kötelezővé - esetenként csak lehetővé - tették az országban élő más nemzetiségek nyelvének hivatalos használatát is; emellett minden gyermeknek lehetöleg az anyanyelvén kellett biztosítani a kötelező iskoláztatást, s még a magyar bankjegyeket is tíz nyelven feliratozták. ${ }^{1}$ Minderre a korabeli Európában - Ausztriát nem számítva - nem volt példa, az országban élő nemzetiségek mégsem voltak elégedettek, s csak néhány évtizeddel később, a magyarosítási törekvések idején kezdték felismerni e szabályozás értékeit.

Magyarországtól az első világháború után a győztes nagyhatalmak elcsatolták területének mintegy 2/3-át, aminek következtében magyarok milliói rekedtek az ország új határain kívül. A magyar nyelv hivatalos nyelv maradt Magyarországon, de nem maradt hivatalos nyelv az elszakított területeken. Ettől kezdve ezért egészen más nyelvi jogai vannak a magyar anyanyelvü embereknek Magyarországon és a szomszédos államokban. ${ }^{2}$ Élnek persze magyarok a történelmi Magyarország területén kívül is, hiszen az európai kivándorlási hullámokból a magyarok is kivették a részüket: az utóbbi mintegy két évszázadban Magyarországról és a szomszédos országokból igen sok magyar vándorolt ki és telepedett le a nagyvilágban. Az így kialakuló diaszpóra magyarságnak a nyelvi jogai ismét különböznek mind a mai Magyarország területén élő magyarok, mind a szomszédos országokban élő magyarok nyelvi jogaitól: a diaszpórában élő magyarok - szemben a Magyarországon élö magyarokkal - nem élvezik a hivatalos nyelvi jogokat, minthogy a magyar nyelv nem hivatalos nyelv azokban az államokban, ahol élnek, de nem élveznek olyan kisebbségi nyelvi jogokat sem, mint amilyeneket a szomszédos államokban élő magyar anyanyelvü személyek. A helyzetet tovább bonyolítja, hogy a Magyarországon és a nagyvilágban élő magyarok általában elégedettek nyelvi jogaikkal, 
jóllehet ezek a jogok nagyon különböznek egymástól, ugyanakkor némely szomszédos országban az ott élő magyarok elégedetlenek a nyelvi jogaikkal, melyek gyengébbek ugyan a magyarországi magyarok nyelvi jogainál, de jóval erősebbek a diaszpórában élő magyarokat megillető nyelvi jogoknál.

A kirajzolódó kép elgondolkodtató: térhez kötöttek lennének a nyelvi jogok, vagy legalábbis bizonyos nyelvi jogok? Attól függően tehát, hogy hol él valaki, más és más nyelvi jogok illetik meg? Milyen természetü jogok akkor a nyelvi jogok és milyen természetü a nyelvi igazságosság? És megoldhatók-e azok a problémák, amelyek a nyelvi jogok körében - és persze nemcsak magyar összefüggésben - időről időre fölmerülnek?

Mindezekkel kapcsolatban három tételt igyekszem megvilágítani és igazolni az alábbiakban. Az első az, hogy a filozófia sokat foglalkozik a nyelvvel, ugyancsak sokat foglalkozik a jogokkal, de nagyon kevéssé törődik a nyelvi jogokkal, holott lenne fontos mondandója - a filozófiának ily módon van egy bizonyos adóssága a nyelvi jogokkal kapcsolatban. A második tétel úgy hangzik, hogy a jogtudomány, föként a nemzetközi jog tudománya régtől fogva számon tartja és vizsgálja a nyelvi jogokat, de jobbára csak a kisebbségi nyelvi jogokat, s úgy tünik, ez a megközelítés súlyos elméleti zavarokhoz vezet - így aztán van mit tennie a jogtudománynak is. A harmadik tétel végül az, hogy bár a hivatalos nyelv intézményéhez kötődő problémákról általában azt tartják, hogy ezek elméleti engedmények nélkül megoldhatatlanok, lehetséges e problémáknak olyan megoldása is, amely nem, vagy csak jóval kisebb mértékben igényel ilyen engedményeket, s e megoldásban kulcsszerepet játszik a térhez kötöttség.

\section{A nyelvi jogok és a filozófia}

A filozófusok a nyelvi fordulat óta megkülönböztetett figyelmet szentelnek a nyelvnek; ezt jól mutatja, hogy egy ideje már a filozófia külön ágaként tartják számon a nyelvfilozófiát. Ezért legalábbis meglepő, hogy a filozófusok a legutóbbi időkig szinte egyáltalán nem foglalkoztak a nyelvi jogok kérdésével. Nehéz megérteni, hogy miközben a nyelvvel kapcsolatban már úgyszólván minden apróságot vizsgálat tárgyává tettek, sokáig kívül maradt a látókörükön ez az érzékeny kérdéskör. Még furcsább a helyzet, ha figyelembe vesszük, hogy a filozófusok immár több mint 300 éve nagy buzgalommal vizsgálják, hogy megilletik-e az embereket bizonyos természetes vagy emberi jogok, $\mathrm{s}$ ha igen, melyek ezek, ám hosszú időn át föl sem vetették a nyelvi jogok kérdését. Hobbes, Locke vagy Rousseau esetében ez még talán érthető, Millnél már kevésbé, Rawls-nál viszont már érthetetlen.

Akadtak persze régebben is filozófusok, gondolkodók, akik foglalkoztak a nyelvi jogok kérdésével. Közéjük tartozott Eötvös József, akinek a 19. század uralkodó eszméiről szóló - 1853-ban és 1856-ban megjelent - könyvéről egy korabeli francia recenzens azt írta, hogy a szabadság kérdését „,magasabb nézőpontból tárgyalja, mint Mill munkája". ${ }^{3}$ Nos, Eötvös ebben a könyvében komoly elemzést adott a nyelvkülönbségröl, s a vele kapcsolatos problémák megoldásának lehetőségeiröl is.

Mintegy fél évszázaddal később, 1907-ben jelent meg Otto Bauer (1907) könyve A nemzetiségi kérdés és a szociáldemokrácia címmel, és bár Bauer Eötvöstől eltérően marxista-szociáldemokrata nézőpontból vizsgálta a nyelvkülönbség kérdését, Eötvöshöz hasonlóan az autonómia elvének alkalmazásában látta a megoldás lehetöségét.

Szintén elvi, filozófiai alapokra támaszkodott az első világháború után létrehozott nemzetközi kisebbségvédelmi rendszer, bár ennek kimunkálásában a filozófiának inkább csak közvetve jutott szerep. ${ }^{4}$ Mindenesetre a kisebbségvédelmi rendszer létrejöttét a liberalizmus győzelmeként ünnepelték az USA-ban (vö. Kymlicka, 1991, 210. o.), s a rendszernek volt némi filozófiai visszhangja is. 
A második világháború után a kisebbségvédelem háttérbe szorult: meghatározóvá vált az a nézet, hogy amennyiben mindenki számára biztosított az emberi jogok élvezete, nincs is szükség rá. A filozófusoknak e változáshoz sem volt sok közük, a filozófia mégis belekeveredett azokba a vitákba, amelyeket e felfogás hívei vívtak a kisebbségi jogok híveivel. Ez a vita ugyanis egyre inkább összekapcsolódott az amerikai filozófián belül zajló egyik vitával: „Az a kevés teoretikus, aki az 1970-es és 80-as években foglalkozott a témával, feltételezte, hogy a kisebbségi jogokról folyó vita lényegét tekintve azonos a »liberálisok" « és »kommunitáriusok« közötti (vagy az »individualisták« és a »kollektivisták« közötti) vitával.” (Kymlicka, 2001, 18. o.) S ez a kevés teoretikus a kisebbségi jogok elismerésének híveit tekintette kommunitáriusnak, illetőleg „,kollektivistának", a kisebbségi jogok elismerésének ellenzőit pedig liberálisnak, illetőleg „individualistának”.

Vagyis, míg az első világháború után még a liberalizmus győzelmeként ünnepelték a kisebbségvédelmet, addig a második világháború után egyre inkább a liberalizmussal filozófiailag szemben álló törekvésként fogták fel - és mindehhez a kortárs filozófusoknak egyik esetben sem volt túl sok közük.

Az igazi változást a 20. század utolsó két évtizede hozta meg, amikor valóban megélénkült és elmélyült a filozófiai érdeklődés a nemzeti, etnikai és kulturális sokféleséggel, valamint a nyelvi, etnikai és kulturális jogokkal kapcsolatban, s ez igen hamar érdemleges eredményekhez is vezetett: kibontakozott egy új filozófiai irányzat, amelyet általában liberális kulturalizmusnak neveznek. Az irányzat képviselői ugyan számos ponton mindmáig eltérő álláspontot foglalnak el, de mindannyian kritikusan viszonyulnak az 1989 előtti időszak uralkodó felfogásához. A fordulatról és annak jelentőségéről Kymlicka, az irányzat legismertebb filozófusa egy helyütt a következőket írta: „Véleményem szerint ez az igazságosságról szóló vita a végéhez közeledik. Mint korábban már megjegyeztem, sok tennivaló van még hátra a bevándorló multikulturalizmus és a kisebbségi nacionalizmus különféle formái igazságosságának értékelésével kapcsolatban. De annak az általánosabb kérdésnek a szempontjából, hogy vajon a kisebbségi jogok természetüknél fogva igazságtalanok-e, a vitának vége: a kisebbségi jogok védelmezői győzelmet arattak." (Kymlicka, 2001, 33. o. $)^{5}$

A filozófia ezzel kétségkívül törlesztett valamit a nyelvi jogokkal kapcsolatban felhalmozott adósságából. A folyamat azonban - úgy tünik - elakadt, mivel az irányzat Kymlicka és Patten által képviselt fő vonulata a lényeget illetően lehorgonyzott annál az álláspontnál, hogy az egyéni emberi jogokat ki kell egészíteni bizonyos kisebbségi jogokkal, s hogy meg kell találni egy új nemzeti, regionális vagy transznacionális mechanizmust, melynek keretében a kormányzatok elszámoltathatók mind az emberi jogok, mind pedig a kisebbségi jogok tiszteletben tartásáért (vö. Kymlicka, 2001, 88. o.). Ez azonban ahogy én látom - még távolról sem tekinthető a filozófiai feladat kielégítő megoldásának.

De mi lehet a megoldás és milyen úton lehet oda eljutni? A magam részéről úgy vélem, a filozófia voltaképpen magában hordja ezt a megoldást, csak elő kell belőle hívni: kifejezetté kell tenni azt, ami egyelőre még csak rejtetten, implicit módon van meg benne. Ez egyebek közt az alábbi két úton lehetséges: egyrészt olyan jelentős hatású filozófiai érveknek a nyelvi jogok kérdésére való alkalmazásával, amely érvekkel egyes nem nyelvi emberi jogok elismerését indokolták, másrészt pedig bizonyos, már széles körben elismert nem nyelvi emberi jogok nyelvi implikációinak a kibontásával. Lássunk ezekre egy-egy példát.

Kezdjük egy jelentős hatású filozófiai érvvel; azzal, amely egykor engem vezetett el a nyelvszabadság eszméjéhez. Az érv John Rawls Az igazságosság elmélete címủ müvéből való. Helyezkedjünk bele ezért Rawls igazságosság-elméletébe: abba az elméletbe, amely a Platóntól kiinduló hagyományt követve a ,jól berendezett" társadalom alapvető elveiről, illetve ezeknek az elveknek a felismeréséről, elfogadásáról és igazolásáról szól 
(Rawls, 1997, 23., 27., 37-42. o.). Az elmélet - Rawls (1997, 12. o.) szavaival - ,a társadalmi szerződés elméletének Locke, Rousseau és Kant által képviselt hagyományos elméletéhez” kapcsolódik, ennek az elméletnek az ,általánosítása és - az elvonatkoztatást illetöen - magasabb szintre emelése".

Képzeljük most el ezen az elméleten belül a Rawls által gondosan felvázolt „eredeti helyzetet”, vagyis azt a helyzetet, amely ebben az elméletben ,ugyanazt a szerepet tölti be, mint a társadalmi szerződés hagyományos elméletében a természeti állapot" (Rawls, 1997, 31. o.). Ez a helyzet Rawlsnál már „pusztán hipotetikus” állapot, mely az igazságosság, illetve a jól berendezett társadalom alapvető elveinek felismerését szolgálja; egyebek közt azzal, hogy a szerződő felek ,a tudatlanság fátyla mögött” választják meg a szóban forgó elveket (Rawls, 1997, 12., 23., 30-33. o.).

Ebben az eredeti helyzetben a szerződő felek tudják például, hogy különféle vallási és erkölcsi meggyőződéseik vannak, de nem tudják, hogy mely vallás vagy erkölcsi meggyőződés követői, s hogy saját vallási vagy erkölcsi felfogásuk többségben vagy kisebbségben van-e társadalmukban. Az eldöntendő kérdés számukra az, hogy milyen elvet fogadjanak el a polgárok szabadságainak korlátozására, illetve szabályozására. És Rawls (1997, 252. o.) úgy vélte, a felek számára ilyen körülmények között „,az egyenlő lelkiismereti szabadság" az egyedüli elv, amelyet elismerhetnek.

„Nem tehetik kockára szabadságukat annak megengedésével, hogy az uralkodó vallási vagy erkölcsi tan tetszése szerint üldözhesse vagy elnyomhassa a többi vallást vagy erkölcsi felfogást. Még ha föltesszük is (vitathatóan), hogy valószínübb, hogy valakiröl majd az derül ki, hogy a többséghez tartozik (már ha van többség), ez a hazardírozás arra vallana, hogy az illető nem vette komolyan az emberek vallási vagy erkölcsi meggyőződéseit, illetve nem értékelte nagyra a szabadságot e meggyőződések gyakorlására. Ám nem hagyhatnák jóvá a felek a hasznosság elvét sem. Ebben az esetben ugyanis szabadságuk alá lenne vetve a társadalmi érdekek latolgatásának, s felhatalmazást adnának korlátozására, ha ez a vágyak teljesülésének nagyobb, végső egyenlegéhez vezetne.” (Rawls, 1997, 252-253. o.)

De nem képzelhetjük-e el éppígy - merült fel bennem egykor a gondolat -, hogy az eredeti helyzetben a szerződő felek azt is tudják, hogy különféle nyelveket beszélnek, hogy különféle nyelvüek, ám nem tudják, hogy mely nyelv a sajátjuk, s hogy saját nyelvük többségben vagy kisebbségben van-e társadalmukban? Nos, nyilván elképzelhetjük, sőt el is kell képzelnünk, hiszen amellett, hogy az embereknek különféle vallási és erkölcsi meggyőződéseik vannak, tény az is, hogy az embereknek különböző nyelveik vannak, hogy más és más nyelven élik az életüket. Nem lehet kétséges továbbá, hogy vallásukhoz és erkölcsi meggyőződéseikhez hasonlóan nyelvük is alapvető jelentőségű számukra, hiszen nyelv nélkül nem is tudnának emberi életet élni, ám sokan közülük csak egyetlen nyelvet beszélnek és értenek, a sajátjukat, s még azok is, akik beszélnek és értenek egy vagy több más nyelvet is, rendszerint a sajátjukat beszélik és értik a legjobban, s a sajátjukat használják a legszívesebben és a leggyakrabban. Következésképpen abba az eldöntendő kérdésbe, hogy a szerződő felek milyen elvet fogadjanak el a polgárok szabadságainak korlátozására, illetve szabályozására, beletartozik a nyelvi kérdés is.

És vajon mely elv lenne elfogadható a felek számára ilyen körülmények között? Nos, úgy tünik - vontam le a következtetést -, hogy ,az egyenlö nyelvszabadság” az egyedüli elv, amelyet a felek elismerhetnének. Nem tehetnék kockára ugyanis szabadságukat annak megengedésével, hogy az uralkodó nyelv tetszése szerint üldözhesse vagy elnyomhassa a többi nyelvet. Még ha föltesszük is (vitathatóan), hogy valószínübb, hogy valakiről majd az derül ki, hogy a többséghez, a nyelvi többséghez tartozik (már ha van többség), ez a hazardírozás arra vallana, hogy az illető nem vette komolyan az emberek 
nyelvének értékét, illetve nem értékelte nagyra a szabadságot e nyelvek használatára. Ám nem hagyhatnák jóvá a felek a hasznosság elvét sem. Ebben az esetben ugyanis szabadságuk, nyelvszabadságuk alá lenne vetve a társadalmi érdekek latolgatásának, s felhatalmazást adnának korlátozására, ha ez a vágyak teljesülésének nagyobb végső egyenlegéhez vezetne.

Nagyjából így szólt tehát az érvelésem a nyelvszabadság mellett: nem tettem mást, csak alkalmaztam Rawls érvét a nyelvi kérdésre (vö. Andrássy, 1993, 2. o.). Megjegyzem, Rawls (252. o. 8. lábjegyzet) maga is utalt az ilyen alkalmazási lehetőségekre, hiszen az egyenlő lelkiismereti szabadság megindokolását így vezette be: ,,az erre az esetre vonatkozó indoklás általánosítható - ha nem is mindig ugyanazzal a meggyőző erővel - más szabadságokra vonatkozóan is".

Lássunk ezek után egy példát arra, hogy miként lehet kibontani ugyanezt a nyelvi jogot egy már elismert nem nyelvi emberi jogból. Az, hogy minden embernek vannak bizonyos természetes vagy emberi jogai, már a 18. században széles körben elfogadott nézetté vált, nem kis részben a jogokra vonatkozó filozófiai vizsgálódásoknak köszönhetően. Mindenesetre ez idő tájt Európában már ,jogi közhelynek számított”, hogy az, ,élethez és testi épséghez való jogban" benne foglaltatik, ,a tagok szabad használatához való jog", amelyből többek között „,a haj és körmök tetszés szerinti vágásához való természetes jog" is következik. Szinte minden tankönyv kifejtette továbbá ,az érzék- és beszélőszervek szabad használatának jogát" (vö. Sólyom, 1985, 13. o.), ám ebből sem a filozófusok, sem a jogászok nem vontak le további következtetéseket, holott lehetett és kellett is volna. Nézzük meg, hogyan!

A beszélőszervek beszéd céljára használhatók, beszélni viszont csak valamely nyelven lehet; minthogy pedig az emberek különféle nyelveken beszélnek, óhatatlanul fölmerül a kérdés, hogy vajon mely nyelven vagy nyelveken van joga minden embernek a beszélőszervek szabad használatának természetes jogához.

Nos, elméleti megközelítésben úgy tünik, mindenkinek elsősorban a saját nyelvén van

Ha azonban mindenkinek joga van beszélöszerve szabad használatához a saját nyelvén és bármely más nyelven is, akkor nyilván joga van mindenkinek ahhoz is, hogy alkalmasint ó döntse el, hogy mely nyelven kivánja a beszélószervét használni. Ez viszont azt jelenti, hogy mindenkinek természetes vagy emberi joga van egy még csak kevéssé ismert szabadsághoz, a nyelvválasztás szabadságához vagy nyelvszabadsághoz. És véleményem szerint ez az a következtetés, amelyet le kellett volna vonniuk mind a filozófusoknak, mind a jogászoknak már legkésóbb a 19. században. Ehhez képest a nyelvszabadság még mindig csak implicit módon része az emberi jogok filozófiájának. Sovány vigasz, hogy a nyelvszabadság egyelóre hiányzik az emberi jogok legtöbb jogi dokumentumából is. joga beszélőszervének szabad használatához, hiszen sokan nem is képesek a saját nyelvükön kívül más nyelven beszélni. Ha tehát joguk van beszélőszerveik szabad használatához és csak a saját nyelvüket beszélik, akkor joguk kell legyen ahhoz, hogy ezen a nyelven élvezzék a beszélöszerveik használatához való jogukat. De mely nyelven vagy nyelveken van joguk beszélöszerveik szabad használatához azoknak a személyeknek, akik a saját nyelvükön kívül beszélnek még egy vagy 
több más nyelvet is? Elvben elképzelhetö, hogy csak azon az egy vagy több nyelven, amely különbözik a saját nyelvüktöl. Gondoljunk azonban bele, hogy az anyanyelvét, az első nyelvét senki nem választja; ahhoz tehát, hogy valaki megtanulhasson egynél több nyelven beszélni, már kell legyen saját nyelve. S mivel eleinte csak ezt a nyelvet beszéli, joga kell legyen ahhoz, hogy beszélöszerveit ezen a nyelven használja, ám abban a pillanatban, amint megtanult egy másik nyelvet, el kellene veszítenie ezt a jogát, s innen kezdve csak az újonnan megtanult nyelven lenne joga beszélőszervei szabad használatához. Talán nem szükséges a további vonzatokat ecsetelni ahhoz, hogy belássuk: mindez teljességgel irracionális. A dolog tehát valóban úgy áll, hogy mindenkinek elsősorban a saját nyelvén van joga beszélőszerveinek szabad használatához.

Joga van azonban mindenkinek a saját nyelvén kívül bármely más nyelven is beszélöszerve szabad használatához. E jog hiányában ugyanis még akár az is megtörténhetne, hogy ellehetetlenül a nyelvi érintkezés a különböző nyelvü emberek között, ez pedig ismét teljességgel irracionális lenne.

Ha azonban mindenkinek joga van beszélőszerve szabad használatához a saját nyelvén és bármely más nyelven is, akkor nyilván joga van mindenkinek ahhoz is, hogy alkalmasint ö döntse el, hogy mely nyelven kívánja a beszélőszervét használni. Ez viszont azt jelenti, hogy mindenkinek természetes vagy emberi joga van egy még csak kevéssé ismert szabadsághoz, a nyelvválasztás szabadságához vagy nyelvszabadsághoz. És véleményem szerint ez az a következtetés, amelyet le kellett volna vonniuk mind a filozófusoknak, mind a jogászoknak már legkésőbb a 19. században. Ehhez képest a nyelvszabadság még mindig csak implicit módon része az emberi jogok filozófiájának. Sovány vigasz, hogy a nyelvszabadság egyelöre hiányzik az emberi jogok legtöbb jogi dokumentumából is.

\section{A nyelvi jogok és a nemzetközi jog}

A 20. század elején a nemzetközi jogi gondolkodásban kezdett eluralkodni egy olyan szemlélet, amely a nyelvi jogokkal összefüggésben mind a mai napig erősen érezteti hatását. A kisebbségi szemléletröl van szó. Ennek elterjedésében döntő szerepet játszott, hogy az első világháború után a győztes nagyhatalmak létrehoztak egy olyan nemzetközi jogi rendszert, amely a faji, vallási és nyelvi kisebbségek védelmét szolgálta. Sajnos e rendszerrel kapcsolatban számos félreértés keletkezett: szívósan tartja magát például az a nézet, hogy a rendszer föként kisebbségi jogokat, köztük kisebbségi nyelvi jogokat ismert el. Az igazság ezzel szemben az, hogy a rendszer magvát alkotó rendelkezések föként polgári és politikai jogokat, azaz szabadságjogokat ismertek el minden állampolgár számára, s csak mintegy kiegészítésül ismertek el néhány kisebbségi jogot. Témánk szempontjából különösen fontos a rendszer modellszerződésének, a Lengyel Kisebbségi Szerződésnek a 7. cikke, s ezen belül a (3) bekezdés, mely így hangzott:

„Egyetlen lengyel állampolgár sem korlátozható egyetlen nyelv szabad használatában sem a magánérintkezésben, a kereskedelemben, a vallási életben, a sajtó útján történő vagy bármilyen természetü közzététel terén vagy a nyilvános gyüléseken." (vö. Halmosy, 1983, 87. o.)

Nyilvánvaló, hogy ez a rendelkezés a nyelvhasználat szabadságát vagy röviden a nyelvszabadságot ismerte el; ennek ellenére úgy szokták értelmezni, hogy a kisebbségekhez tartozó személyek jogát ismerte el a saját nyelvük használatára egy bizonyos körben (ld. pl. Cloude, 1955, 18-19. o.; Capotorti, 1979, 18-19. o.; Thornberry, 1991, 42-43. o.; de Varennes, 1996, 26-27. o.; Szalayné, 2003, 89-90. és 92. o.; minderről bővebben ld. 
Andrássy, 2013, 238-261. o.). Ez az interpretáció kétszeresen is hibás: egyfelől a jog alanyai nem a nyelvi kisebbségekhez tartozó személyek voltak, hanem minden lengyel állampolgár, másfelől pedig a rendelkezés nem csupán a saját nyelv, hanem bármely nyelv szabad használatának jogát ismerte el.

A II. világháború kitörésének idejére összeomlott a nemzetközi kisebbségvédelmi rendszer, s a háború után nem állították helyre müködését. Az események új irányt vettek: létrejött egy új világszervezet, az ENSZ, amely már Alapokmányában elkötelezte magát az emberi jogok tiszteletben tartása mellett, s ezt követően meg is kezdődtek az emberi jogok kodifikálására irányuló munkálatok. Ezzel ismét megnyílt a lehetőség a nyelvszabadság nemzetközi elismerése előtt, éspedig minden eddiginél ígéretesebb módon, hiszen most már nem egy kisebbségvédelmi rendszer jogának kimunkálása volt napirenden, hanem az emberi jogok nemzetközi elismerése.

Éppen ezért nehéz megérteni, hogy 1948-ban, amikor az ENSZ Közgyülése elfogadta az Emberi Jogok Egyetemes Nyilatkozatát, hogyan hagyhatta ki ebből a nyelvszabadságot. Még nehezebb azonban megérteni, hogy az ENSZ Közgyülése később, 1966-ban egy kisebbségi nyelvi jogot ismert el a Polgári és Politikai Jogok Nemzetközi Egyezségokmányának 27. cikkében. A cikk szövege így szól:

„Azokban az államokban, ahol etnikai, vallási vagy nyelvi kisebbségek léteznek, az ilyen kisebbségekhez tartozó személyektől nem lehet megtagadni azt a jogot, hogy csoportjuk más tagjaival közösségben saját kultúrájukat élvezzék, hogy saját vallásukat vallják és gyakorolják, vagy hogy saját nyelvüket használják."

Az Egyezségokmány e cikke három jogot ismer el: az etnikai kisebbségekhez tartozó személyek számára a saját kultúra élvezetéhez, a vallási kisebbségekhez tartozó személyek számára a saját vallás megvallásához és gyakorlásához, s a nyelvi kisebbségekhez tartozó személyek számára a saját nyelv használatához való jogot (Capotorti, 1979, 590. o. 17. lábjegyzet). Ha a cikk szövegéből kiemeljük a nyelvi jogot, az alábbi eredményt kapjuk:

„Azokban az államokban, ahol [...] nyelvi kisebbségek léteznek, az ilyen kisebbségekhez tartozó személyektől nem lehet megtagadni azt a jogot, hogy csoportjuk más tagjaival közösségben [...] saját nyelvüket használják."

A szövegnek - ahogy én látom - két nagy hibája van: az egyik a jog alanyaival, a másik a jog tartalmával kapcsolatos. A jog alanyait illetően a probléma a következő: miért csak a nyelvi kisebbségekhez tartozó személyektől nem lehet megtagadni azt a jogot, hogy a saját nyelvüket használják, más szóval a nyelvi többséghez tartozó személyektől miért lehet megtagadni ugyanezt a jogot? Ez teljesen irracionális, és nyilvánvaló, hogy az ENSZ Közgyülése sem kívánta ezt lehetővé tenni. A jogalany-meghatározás ettől még persze hibás, s ezért ki kellene javítani, ami nem is lenne nehéz: ki kellene mondani, hogy senkitől sem lehet megtagadni a jogot, hogy a saját nyelvét használja, vagy hogy mindenkinek joga van a saját nyelve használatához.

Az Egyezségokmány 27. cikke véleményem szerint hibásan definiálja az általa elismert nyelvi jog tartalmát is. Egyetértek azzal, hogy a jogalanyoktól nem lehet megtagadni a saját nyelvük használatához való jogot. De miért ne tanulhatnának és használhatnának más nyelvet is, ha úgy akarják? Ezt a jogot miért lehet tölük megtagadni? Ez ellentmond minden ésszerűségnek, s nyilvánvaló, hogy az ENSZ Közgyülése sem kívánta lehetővé tenni ezt a korlátozást.

Ha a mondottakból kiindulva kijavítjuk a 27. cikkben elismert nyelvi jog tartalmának definícióját, akkor azt kapjuk, hogy a jogalanyoktól nem lehet megtagadni sem azt a jogot, hogy a saját nyelvüket használják, sem pedig azt a jogot, hogy más nyelveket hasz- 
náljanak. Ez esetben viszont nyilván nem lehet megtagadni tőlük azt a jogot sem, hogy adott körülmények között ők válasszák meg, hogy mely nyelvet fogják használni. Ez azonban azt jelenti, hogy a jogalanyoktól nem lehet megtagadni a jogot az általuk használt nyelv megválasztásához, más szóval a nyelvszabadsághoz. Eszerint az Egyezségokmány megalkotóinak a 27. cikkben elismert nyelvi jog tartalmát úgy kellett volna meghatározniuk, hogy a jogalanyoktól nem lehet megtagadni a jogot a nyelvszabadsághoz.

Az emberi jogok univerzális nemzetközi jogának ezek a nyelvi jogokkal kapcsolatos gyengeségei természetesen nem maradtak következmények nélkül a regionális nemzetközi jog fejlődésére sem: Európában a nyelvi jogok nemzetközi elismerésére már egy külön kisebbségvédelmi egyezményben került sor, éspedig úgy, hogy az Emberi Jogok Európai Egyezménye nem tartalmazza az Egyezségokmány 27. cikkében foglalt nyelvi jogot sem.

A jogalkotás gyengeségeit a joggyakorlat sokszor szintén továbbörökíti, de olykor ellensúlyozza vagy ki is javítja, s ez áll a Polgári és Politikai Jogok Nemzetközi Egyezségokmányára is. Az Egyezségokmánnyal kapcsolatos joggyakorlatot elsősorban az ENSZ Emberi Jogi Bizottsága alakítja, s a Bizottság a Ballantyne, Davidson, McIntyre ügyben adott jogértelmezésével továbbörökítette azt a hibát, amelyet az Egyezségokmány megalkotói az Egyezségokmány 27. cikkében elismert nyelvi jog jogalanyainak hibás definiálásával követtek el. Másfelől viszont a Bizottság ugyanebben az ügyben kerülö úton korrigálta is ezt a jogalkotói hibát, sőt korrigálta a 27. cikkben elismert nyelvi jog tartalmának meghatározása során elkövetett jogalkotói hibát is, amikor kimondta, hogy az Egyezségokmány 19. cikkében elismert kifejezési szabadság magában foglalja az összes ember, így a nyelvi többséghez tartozó valamennyi személy szabadságát is „önmaga kifejezésére a maga által választott nyelven”. Ezzel az Emberi Jogi Bizottság elismerte minden ember jogát a nyelvszabadsághoz, s ily módon némiképp pótolta a nyelvszabadság jogalkotói elismerésének hiányát.

\section{A hivatalos nyelv problémájának megoldásához: a tér szerepe}

A nyelvszabadság - mint láttuk - magánéleti szabadság, a tágabb értelemben vett magánélet szféráira terjed ki. Kérdés, milyen következtetések adódnak a nyelvhasználat közéleti színtereire, a hivatalos nyelvhasználatra vonatkozóan. A hivatalos nyelvvel kapcsolatos problémák túlnyomó többsége abból fakad, hogy az államok csak egy, legfeljebb két-három élő nyelvet választanak hivatalos nyelvvé 6 , s így azoknak a személyeknek, akiknek a nyelve megegyezik a hivatalos nyelvvel vagy az ilyen nyelvek egyikével, lehetővé teszik, másoktól viszont megtagadják, hogy saját nyelvüket hivatalos nyelvként is használják. Ez azonban megkülönböztetés, amely sérti a diszkrimináció tilalmát, de sérti az egyenlö jogvédelemhez való jogot is: más szóval az államok gyakorlata többszörösen is emberi jogokat sért, és ezért igazságtalan. A szóban forgó jogsérelmek, illetve igazságtalanságok kiküszöbölésére régi, már-már klasszikus források szerint (ezekről ld. Pool, 1991) csak két lehetőség kínálkozik: az egyik az, hogy a világ minden államában hivatalos nyelvvé teszik az összes ember nyelvét, vagyis az összes élő nyelvet, a másik pedig az, hogy a világ minden államában egy vagy több olyan nyelvet nyilvánítanak hivatalos nyelvvé, amely nem azonos egyetlen ember saját nyelvével sem. ${ }^{7}$ Egyik megoldás sem látszik azonban sem ésszerünek, sem kivihetőnek a jelenlegi körülmények között. Az első azért nem, mert az élő nyelvek száma jelenleg mintegy 7000, és még elképzelni is nehéz, hogy minden államnak 7000 hivatalos nyelve legyen. A másik megoldás pedig azért tünik irracionálisnak és irreálisnak, mert egyebek közt azt jelentené, hogy senkinek sem lenne joga a saját nyelvén tanulni.

Mi lehet akkor az a megoldás, amely igazságos, s egyúttal gyakorlati szempontból is kivitelezhető nagyobb nehézségek nélkül? Véleményem szerint először is fel kell ismer- 
ni, hogy mindenkinek emberi joga van a saját nyelve hivatalos nyelvként való használatához. Ennek belátásához forduljunk az Emberi Jogok Egyetemes Nyilatkozata felé.

A Nyilatkozat 10. cikke elismeri mindenki jogát a független és pártatlan bírósághoz, 26. cikke pedig elismeri mindenki jogát az oktatáshoz. De vajon mely nyelven gyakorolhatók e jogok? Erröl mindkét cikk hallgat. Márpedig rendes körülmények között „,bírósági tárgyalást" tartani lehetetlen valamely nyelv használata nélkül, és rendes körülmények között nem lehetséges „elemi oktatás”, „technikai és szakoktatás” és „felsőoktatás” sem legalább egy nyelv használata nélkül. Ha azonban ez így van, akkor a kérdés eleve emberi jogi kérdés, s így szükségképpen emberi jogi lesz a rá adott válasz is. De mi lehet ez a válasz?

Nézetem szerint az, hogy mindenkinek a saját nyelvén van elsősorban joga a független és pártatlan bíróság előtti tárgyaláshoz és az oktatáshoz is. Így kell ennek lennie, hiszen nagyon sok ember nem is beszél más nyelvet a sajátján kívül: ha pedig ezeknek az embereknek joguk van a független bíróság előtti tárgyaláshoz és az oktatáshoz, akkor joguk kell legyen ahhoz is, hogy a saját nyelvükön élvezzék ezeket a jogokat. De joguk kell legyen e jogok saját nyelven való élvezetéhez azoknak is, akik a saját nyelvükön kívül beszélnek egy vagy több más nyelvet is. Ha ugyanis nem így lenne, ez azt jelentené, hogy abban a pillanatban, amikor valaki megtanul egy nyelvet a sajátján kívül, elveszíti a jogát ahhoz, hogy a saját nyelvén élvezze a független és pártatlan bíróság elötti tárgyaláshoz, valamint az oktatáshoz való jogát, ami viszont teljes képtelenség és irracionalitás. Ezért mindenkinek valóban a saját nyelvén van elsősorban joga az Egyetemes Nyilatkozat 10. és 26. cikkében elismert jogokhoz. Ez pedig azt jelenti, hogy mindenkinek emberi joga van a saját nyelve hivatalos nyelvként való használatához és a saját nyelvü oktatáshoz.

Ha viszont ez igaz, akkor - úgy tünik - minden államban hivatalos nyelvvé ${ }^{8}$ kell tenni minden ember nyelvét, vagyis az összes élő nyelvet, ami azonban, tekintve, hogy az élö nyelvek száma jelenleg mintegy $7000^{9}$, irracionális és egyelöre kivehetetlennek is látszik. Lehetséges-e ezek után olyan megoldás, amely nem vagy csak minimális mértékben igényel elméleti kompromisszumokat és ésszerüen átültethető a gyakorlatba is?

Véleményem szerint lehetséges. Ennek felismeréséhez észre kell vennünk, hogy abban a következtetésben, mely szerint „ha mindenkinek emberi joga van a saját nyelve hivatalos nyelvként való használatához, akkor minden államban hivatalos nyelvvé kell tenni valamennyi ember nyelvét", van egy rejtett, ki nem mondott elöfeltevés: az, hogy mindenkinek mindenhol joga van az emberi jogokhoz.

Csakhogy vannak olyan emberi jogok is, amelyek mindenkit megilletnek, de nem mindenhol. A legjobb példát erre a politikai jogok szolgáltatják. Az Emberi Jogok Egyetemes Nyilatkozatának 21. cikke, s közelebbről e cikk (1) bekezdése például így hangzik:

„Mindenkinek joga van ahhoz, hogy részt vegyen hazája közügyeinek igazgatásában közvetlenül vagy szabadon választott képviselök útján.”

Eszerint a szóban forgó politikai jogok mindenkit megilletnek, de nem mindenhol. És ilyen jognak kell lennie a saját nyelv hivatalos nyelvként való használata jogának is: ha ugyanis olyan jog lenne, amely mindenkit megillet mindenhol, akkor - mint láttuk - a világ minden államában hivatalos nyelvvé kellene tenni mintegy 7000 nyelvet. Ha azonban a saját nyelv hivatalos nyelvként való használatának joga mindenkit megillet, de nem mindenhol, akkor már nem kell minden államban hivatalos nyelvvé tenni minden nyelvet, s ez már mindjárt ésszerünek tünik.

De vajon hol, a világ mely országában van joga mindenkinek ahhoz, hogy a saját nyelvét hivatalos nyelvként is használja?

Tegyük fel a kérdést először úgy, hogy vajon joga van-e bárkinek is ahhoz, hogy a saját nyelvét hivatalos nyelvként használja azokban az államokban, ahol ezt a nyelvet nem vagy csak alkalmilag beszélik? Nyilván nincs, hiszen azok, akiknek ez a nyelv a saját 
nyelvük, gyakorlatilag nem is élveznék ezt a jogukat. Következésképpen mindenkinek csak azokban az országokban van joga ehhez, ahol ezt a nyelvet beszélik is. S ez ésszerünek és igazságosnak is látszik.

De vajon joga van-e bárkinek is ahhoz, hogy a saját nyelvét hivatalos nyelvként használja azokban az államokban, ahol ezt a nyelvet csak nemrég óta beszélik? A válasz ismét nemleges. Azokban az országokban ugyanis, ahol ezt a nyelvet csak nemrég óta beszélik, e nyelvet többnyire olyan személyek beszélik, akik bevándorlók vagy bevándorlók leszármazottai. ${ }^{10}$ Ha azonban e személyeknek joguk lenne ahhoz, hogy a saját nyelvüket hivatalos nyelvként használják az őket vagy a felmenőiket befogadó államokban, akkor előbb-utóbb ismét kialakulna az a helyzet, hogy mindenkinek mindenhol joga van a saját nyelve hivatalos nyelvként való használatához az egész világon. Márpedig ez - mint láttuk - irracionális. Az ilyen személyeknek ezért nincs joguk ahhoz, hogy a saját nyelvüket hivatalos nyelvként használják új hazájukban. ${ }^{11}$ Ami persze nem jelenti azt, hogy e személyeket egyáltalán ne illetné meg ez a jog valahol a világon; természetesen öket is megilleti ez a jog, csak nem a befogadó országokban.

De akkor végső soron hol van joga mindenkinek ahhoz, hogy a saját nyelvét hivatalos nyelvként használja? Nyilván azokban az országokban, ahol a saját nyelve régtől fogva, hagyományosan beszélt nyelv.

Kérdés azonban, hogy vajon megilletnek-e mindenkit minden ilyen államban ezek a jogok? Tegyük fel, hogy nem; ez esetben viszont, mivel mindenkit megilletnek e jogok valahol a világon, lennie kell legalább egy olyan országnak mindenki számára, amelyben a saját nyelvét régtől fogva, hagyományosan beszélik, és amelyben őt is megilletik a szóban forgó jogok. De melyik ez az állam? Nos, ez különféle tényezők függvénye, de végső soron minden személy esetében meghatározható. Lássuk a főbb eseteket!

Kezdjük azokkal a személyekkel, akik egy olyan országban élnek, ahol a nyelvüket régtől fogva, hagyományosan beszélik és ők épp a nyelvet régtől fogva, hagyományosan beszélő közösségből származnak. Az ilyen személyeknek bizonyosan ebben az országban van joguk ahhoz, hogy a saját nyelvüket hivatalos nyelvként is használják. Ha ugyanis azokat a személyeket, akik a szóban forgó közösségből származnak, nem illeti meg a jog a saját nyelvük használatához, akkor ebben az országban senkit sem illethet meg ez a jog, hiszen kizárólag e személyek és közösségük miatt minősül az ország olyan országnak, ahol az adott nyelvet régtől fogva, hagyományosan beszélik.

Vegyük most azokat a személyeket, akik nem egy olyan országban élnek vagy tartózkodnak, ahol a nyelvüket régtöl fogva, hagyományosan beszélik. A legtöbb ilyen személy bevándorló vagy bevándorlók leszármazottja, de ide sorolhatók a turisták stb. is. Nekik mint láttuk - nem ebben az országban van joguk a saját nyelvük hivatalos nyelvként való használatához. De akkor vajon hol? Nyilván abban az országban, ahová az a terület tartozik, ahonnan származnak (és ahol a nyelvüket régtől fogva, hagyományosan beszélik).

Vegyük végül azokat a személyeket, akik egy olyan országban élnek, ahol a saját nyelvüket régtől fogva, hagyományosan beszélik, de ők maguk nem abból a közösségből származnak, amely ezt a nyelvet itt hagyományosan beszéli. Ilyen személyek mindenekelött azok a bevándorlók, vagy leszármazottaik, akiknek a saját nyelve megváltozott, akik tehát nyelvcserén estek át, és ennek folytán lett a nyelvük azonos új hazájuk hivatalos nyelvével vagy hivatalos nyelveinek egyikével. Vajon mely országban van joguk e személyeknek ahhoz, hogy a saját nyelvüket hivatalos nyelvként is használják? Nyilván itt, az új hazájukban.

Fölmerülnek persze további részletkérdések és más természetü kérdések is, például abból fakadóan, hogy számos élő nyelvnek nincs írásbelisége, s az ilyen nyelvek aligha lehetnek modern értelemben vett hivatalos nyelvek. Milyen hatással van ez a körülmény az ilyen nyelvek beszélöinek arra a jogára, hogy a saját nyelvüket hivatalos nyelvként is használhatják? Nos, ezt és a többi kérdést ez a tanulmány már nem tárgyalhatja. 


\section{Irodalomjegyzék}

Andrássy György (1993): Etnikai kisebbségek és emberi jogok. Regio, 4. 2. sz. http://www.matarka.hu/ cikk_list.php?fusz_kovetk=5252\&elozo$=\mathrm{E} 1 \% \mathrm{C} 5 \% 91 \mathrm{z} \% \mathrm{C} 5 \% \overline{9} 1+\mathrm{sz} \% \mathrm{C} 3 \% \mathrm{~A} 1 \mathrm{~m} \& \mathrm{fusz}$ eloz $=5254$

Andrássy György (2013): Nyelvszabadság. Dialóg Campus Kiadó, Budapest-Pécs.

Bauer, O. (1907): Die Nationalitatfrage und die Sozialdemokratie. Volksbuchhandlung Brand.

Capotorti, Fr. (1979): Study on the Rights of Persons Belonging to Ethnic, Religious and Linguistic Minorities. United Nations, New York.

Cloude, I. (1955): National Minorities: An international Problem. Greenwood Press Publishers, New York.

Halmosy, D. (1983): Nemzetközi szerződések 1918-1945. Közgazdasági és Jogi Könyvkiadó Gondolat Könyvkiadó, Budapest.

Hobhouse, L. T. (1928): Social Evolution and Political Theory. Columbia University Press, New York.

Kymlicka, W. (1991): Liberalism, community and culture. Clarendon Press, Oxford.

Kymlicka, W. (1995): Multicultural citizenship. Clarendon Press, Oxford.

DOI: $10.1093 / 0198290918.001 .0001$
Kymlicka, W. (2001): Politics in the Vernacular. Oxford University Press, Oxford.

DOI: 10.1093/0199240981.001.0001

Laboulay, E. (1860): L'état et ses limites. Revue Nationale et Étrangere.

Patten, A. (2006): Who Should Have Official Language Rights? Supreme Court Law Review.

Pool, J. (1991): The Official Language Problem. American Political science review, 85. 2. sz. 495497. DOI: $10.2307 / 1963171$

Rawls, J. (1997): Az igazságosság elmélete. Osiris, Budapest.

Sólyom László (1985): Mit szabad és mit nem? Valóság, 8. sz.

Szalayné Sándor Erzsébet (2003): A kisebbségvédelem nemzetközi jogi intézményrendszere a 20. században. MTA Kisebbségkutató Intézet - Gondolat Kiadói Kör, Budapest.

Thornberry, P. (1991): International Law and the Rights of Minorities. Clarendon Press, Oxford.

de Varennes, F. (1996): Language, Minorities and Human Rights. Martinus Nijhoff Publishers, Hague.

\section{Jegyzetek}

${ }^{1}$ Igaz, a húsz koronás bankjegy egyik oldalán magyar, a másikon pedig német nyelvűek voltak a fó feliratok, de azért a bankjegyen apró betükkel további nyolc nyelven is el lehetett olvasni azt, hogy húsz korona.

${ }^{2}$ A képet némileg árnyalja, hogy a magyar nyelv regionális szinten ismét hivatalos nyelv lett Szlovéniában és hivatalos használatban levő nyelvvé vált Jugoszláviában, illetve Szerbiában (Vajdaság), valamint néhány magyarlakta ausztriai településen.

${ }^{3}$ A recenzió szerzője (Laboulay, 1860, 183. o.) John Stuart Mill A szabadságról című munkájára utal, mely munka szintén tárgya volt recenziójának.

${ }^{4}$ Leginkább úgy, hogy Wilson elnök és munkatársai olyan javaslatokat terjesztettek elö, amelyek tükrözték az amerikai jogfelfogás elvi alapjait, s ennek folytán a kisebbségvédelmi rendszer rendelkezései nagyrészt összhangban is álltak ezekkel az alapokkal, vagyis azokkal az elvekkel, melyek végső soron az emberi jogokban gyökereznek (vö. pl. Cloude, 1955, 19-20. o.).

${ }^{5} \mathrm{Az}$ idézet elötti néhány bekezdés rövidített formában a nyelvszabadságról írt könyvem egy részletét (Andrássy, 2013, 45-46. o.) ismétli meg.
${ }^{6}$ Vannak persze kivételek: Dél-Afrikában például 11 hivatalos nyelv van.

${ }^{7}$ Ilyen nyelvek például a kihalt nyelvek, köztük a latin, valamint a mesterséges nyelvek, köztük az eszperantó.

${ }^{8}$ A legtöbb államban a hivatalos nyelv egyben közoktatási nyelv is, ezért a továbbiakban a hivatalos nyelv fogalmába beleértem a közoktatási nyelvet is.

${ }^{9}$ Vö. 2015. 06. 26-i megtekintés, Ethnologue, https:// www.ethnologue.com/world

${ }^{10}$ Lehetnek persze erőszakkal betelepült személyek vagy leszármazottaik is, vagyis hódítók, de az is lehet, hogy erőszakkal kitelepítettek (az ezzel kapcsolatos speciális problémákról ld. Patten, 2006).

${ }^{11}$ Erre a következtetésre jutott egyebek közt Kymlicka (1995) és Patten (2006, 101-115. o.). A következtetést megerősíti továbbá, hogy a befogadó államok nem szokták a bevándorlók nyelveit hivatalos nyelvvé tenni, de maguk a bevándorlók és leszármazottaik sem állnak elő ilyen igénnyel. 